ISSN 2518-1521 (Online), ISSN 2226-2830 (Print)

ВІСНИК МАРІУПОЛЬСЬКОГО ДЕРЖАВНОГО УНІВЕРСИТЕТУ

СЕРІЯ: ІСТОРІЯ. ПОЛІТОЛОГІЯ, 2019, ВИП. 25

Centrally East to Europe in posttotalitary days, and their influence, on passing of these processes in Ukraine. Understanding of importance of analysis of sources, that they are used by research workers, working above the study of those or other questions, in there by foreign policy of RP, is a necessary factor for objective, many-sided, critical and impartial research. The aggregate of components of a spring complex, and in concert their classification, is predetermined both a research subject, his purpose and tasks and spatially geographical, by chronologic scopes, and that is why in every concrete case is specific. General for all researches, at the same time, there is a conditionality of quality of results of historical study, validity and authenticity of the got knowledges, by a study and classification of constituents of their spring base.

The archived documents come forward basis of a spring base of research; certificate encyclopaedic edition; concretely sociological and statistical materials of analytical centers; materials of magazines; official speeches, appearances, lectures, statements, memoirs and flashbacks of higher state public servants, politicians and diplomats.

On the whole, powerful spring complex, presented the aggregate of materials of funds of the leading archived establishments of Ukraine, and also certificate encyclopaedic by literature, concretely sociological and by statistical materials, periodicals, memorialist, other, worked out an author taking into account the newest of theory and methodology approaches, is fully sufficient for the independent study of foreign policy of Republic Poland of certain decade. The source-study an analysis of problem is subsoil for forming of own look to the key progress of foreign-policy priorities of $R P$, ground of the successes realization of set tasks attained a country trends. Addition to a spring complex by the new standards of documents and materials on the topic, testify to the necessity of continuation of scientific searches for the set direction.

Keywords: sources, foreign policy, Poland, documents and materials, scientific searches.

\title{
УДК 94(477.52)“1941/1944”
}

\section{О. В. Вербовий}

\section{СТРУКТУРА ТА КОМАНДНИЙ СКЛАД СУМСЬКОГО ПАРТИЗАНСЬКОГО З’СДНАННЯ (1941-1944 РР.)}

В статті досліджено структуру та командний склад Сумського партизанського з'єднання як вагомий фактор впливу на успішність бойової діяльності. Простежено еволюцію та визначено характерні особливості в різні періоди історії Путивльського партизанського загону - Путивльського об'єднаного партизанського загону - Сумського партизанського з'єднання-1-ої Украӥнської партизанської дивізї̈ ім. двічі Героя Радянського Союзу С. А. Ковпака.

Ключові слова: Украӥна в роки Другої світової війни, партизанський рух опору, Сумське партизанське з'єднання.

DOI 10.34079/2226-2830-2019-9-25-26-37

Проблематика історії України в роки Другої світової війни і до сьогодні є вельми актуальною у науковому середовищі, а також має значний суспільний запит. I одним із питань, якому приділяється належна увага в сучасній історичній науці є радянський 
партизанський рух опору. Контрверсійного характеру набувають дослідження, присвячені перегляду кількісного та якісного складу партизанських формувань, переоцінки їх бойової та диверсійної діяльності, вивчення побутових умов життя, взаємовідносин партизанів і командного складу, стосунків 3 місцевим населенням та представниками національновизвольного руху тощо $[48 ; 25 ; 38 ; 31 ; 22 ; 12 ; 19 ; 17 ; 23 ; 24 ; 21 ; 33 ; 18 ; 4 ; 5 ; 32 ; 14 ; 13 ; 20$ та ін.]. На увагу заслуговують не лише загальні проблеми історії радянського підпільнопартизанського руху опору, а й вивчення окремих партизанських з'єднань та загонів. I в першу чергу мова йде про діяльність одного із найбільш успішних з’єднань - Сумського партизанського з'єднання (1-ої Української партизанської дивізії ім. двічі Героя Радянського Союзу С. А. Ковпака). На сучасному етапі ми маємо доступ до документів зарубіжних та вітчизняних центральних, регіональних, галузевих архівних установ, використовуємо дослідження істориків попередніх періодів та публікації щоденників, спогадів, мемуарів командирів та бійців з'єднання: С. А. Ковпака [30; 28; 29; 26; 27 та ін.], С. В. Руднєва [35; 34 та ін.], Г. Я. Базими [1], П. П. Вершигори [7; 9; 11; 10; 8 та ін.], П. Є. Брайка [6], В. О. Войцеховича [16; 15 та ін.], С. П. Тутученка [36; 37 та ін.], Д. І. Бакрадзе [3; 2 та ін.] та ін. У комплексі, все це дає можливість неупередженого та грунтовного аналізу історії становлення, розвитку, бойового шляху Сумського партизанського з'єднання.

Метою даної статті є дослідження структури Сумського партизанського з'єднання та iii еволюції в зв'язку із умовами бойової діяльності та росту підрозділу, а також аналіз кадрового забезпечення командного складу з'єднання / дивізії та його вплив на успішність діяльності Путивльського партизанського загону (Путивльського об'єднаного партизанського загону, Сумського партизанського з'єднання, 1-ої Української партизанської дивізії ім. двічі Героя Радянського Союзу С. А. Ковпака).

Досліджуючи структуру та командний склад Сумського партизанського з'єднання в різні періоди його діяльності, доцільно виокремити три основні етапи. Перший етап існування окремих партизанських загонів (серпень 1941 р. - лютий 1942 р.). Другий етап діяльність Сумського партизанського з'єднання у формі спочатку Путивльського об'єднаного партизанського загону, а пізніше - групи / з'єднання партизанських загонів Сумської області (лютий 1942 р. - лютий 1944 р.). Третій етап - діяльність 1-ї Української партизанської дивізії ім. двічі Героя Радянського Союзу С. А. Ковпака (лютий - листопад 1944 р.). Враховуючи, що структура та командний склад з'єднання формувалися в перший період діяльності й у загальному вигляді фактично залишалися незмінними до кінця існування бойового підрозділу, доцільно простежити їх еволюцію від серпня 1941 р. до листопада 1944 р. $з$ грунтовним аналізом саме початкового періоду.

Впродовж серпня - вересня 1941 р. відбувалося створення та організаційне оформлення партизанських загонів Сумської області, які в січні-лютому 1942 р. об’єдналися в єдину бойову одиницю. 3 перших же днів існування в загонах встановлювалася певна структура, зокрема визначалися відповідальні особи за окремі напрямки діяльності, або ж формувалися групи в залежності від їх функціональних обов'язків. Трішки пізніше організаційну структуру загонів склали оперативні групи в кількості від 10 до 20 бійців, які, в свою чергу, ділилися на відділення.

Першими офіційно оформленими стали загони Глухівського та Шалигінського районів. 27 серпня 1941 р., першими двома наказами по цих загонах призначалося командування та зараховувався особовий склад. Так, командиром Глухівського партизанського загону став П. Л. Кульбака, начальником штабу, на якого покладалося 
ISSN 2518-1521 (Online), ISSN 2226-2830 (Print)

ВІСНИК МАРІУПОЛЬСЬКОГО ДЕРЖАВНОГО УНІВЕРСИТЕТУ

СЕРІЯ: ІСТОРІЯ. ПОЛІТОЛОГІЯ, 2019, ВИП. 25

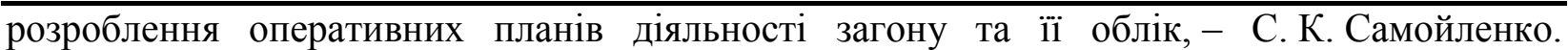
Особовий склад нараховував 52 чоловіка [46, арк. 2]. Уже 28 серпня, наказом № 3, загін було розподілено на дві оперативні групи: 1-а у складі 22 чол. під командуванням I. C. Epeca, 2-a група із 20 чол. під командуванням М. С. Андрієнка. Начальником господарської частини призначався Г. Д. Роман, на якого покладались обов'язки забезпечення загону продуктами і боєприпасами, хоча вже 28 вересня його замінив I. М. Давидов, а 30 січня 1942 р. - П. Г. Шульга [46, арк. 2зв, 5зв, 12зв]. Наказом № 4 від 30 серпня 1941 р. було призначено комісара загону - О. П. Білявського, кандидатуру якого затвердив Сумський обласний комітет КП(б)У [46, арк. 3].

Шалигінський партизанський загін, який був створений 27 серпня і проіснував до 22 жовтня 1941 р. як Холопковський, очолили командир А. Я. Саганюк та комісар Ф. Д. Матющенко. Його особовий склад нараховував 31 чоловік. Наказом призначався "начальник боєживлення" В. В.Строган, а також "начальник господарства" Ф. Н. Потіпака, до якого прикріплювалося три партизани [47, арк. 2-2зв]. Щоправда, вже 19 вересня, у зв'язку з тим, що Ф. Н. Потіпака залишив загін, а також у результаті проведення розслідування фактів розкрадання продуктів харчування його помічником, “начальником господарства i продуктів" загону було призначено С. П. Деркача [47, арк. 6зв]. 17 вересня 1941 р., наказом № 6, у Шалигінському партизанському загоні створювалося три оперативні групи, а також продовжувала функціонувати господарська група: 1-a оперативна група у складі 4 чоловік (старший групи М. Д. Капков), 2-a-8 чол. (старший $\quad$ M. І. Жук), 3-я - 5 чол. $\quad$ (старший Ф. С. Фесенко) [47, арк. 4-4зв]. Наказом № 27 від 31 січня 1942 р., “у зв’язку 3 розгортанням роботи зі зростання партизанського загону”, було призначено начальника штабу Ф. С. Фесенка [47, арк. 19зв].

22 вересня 1941 р. наказом № 1 по Путивльському партизанському загону оголошувався список особового складу загону в кількості 42 чоловіка. Командиром загону був С. А. Ковпак, начальником штабу - М. М. Курс. Особовий склад Путивльського партизанського загону з першого ж дня був умовно поділений на три групи: Путивльська група в складі 9 бійців; група 34 білорусів-диверсантів, які прибули з Харкова напередодні вступу німців; група 328 солдатів 6-ї повітрянодесантної бригади, які потрапили в оточення й приєдналися до партизанів. 3 них було сформовано групу розвідників 3 трьох путивлян на чолі з В. Ф. Поповим та групу мінерів з трьох білорусів-диверсантів на чолі 3 Г. А. Юхновцем. 3 військовослужбовців було сформовано дві “оперативні бойові групи” під командуванням П. Н. Васильєва та Ф. А. Карпенка [42, арк. 1-2].

Пізніше переважна більшість військовослужбовців, які постійно прибували до загону з оточення, були переправлені через лінію фронту в радянський тил. Як зазначав у своїх записках С. А. Ковпак, до 10 жовтня 1941 р., коли був масовий наплив у загін військовослужбовців, партизанами загону було виведено з оточення та перекинуто через лінію фронту до 500 чоловік [33, с. 32].

26 вересня 1941 р. до Путивльського партизанського загону була зарахована група відповідальних працівників Конотопського району в кількості 5 осіб, серед яких і голова районного виконавчого комітету Ф. С. Канавець та районний прокурор В. П. Кочемазов, на яких було покладено завдання з організації партизанського загону. Вони, 3 приходом німецьких військ відступили до лісу, однак не маючи своїх баз, змушені були перейти в Спадщанський ліс [42, арк. 3]. У грудні 1941 р. ними було сформовано Конотопський партизанський загін. 
У серпні 1941 р. в Путивльському районі був організований ще один загін, очолюваний командиром С. В. Руднєвим та начальником штабу Г. Я. Базимою. Він мав дислокуватися в Монастирському лісі. Напередодні вступу німців, 6 вересня 1941 р., за розпорядженням Путивльського районного комітету КП(б)У, командир С. В. Руднєв із 24 бійцями виїхали в м. Суми на курси диверсантів-підривників, де перебували до 11 вересня. I тільки 12 вересня, перейшовши лінію фронту біля с. Тьоткіно Глушковського району Курської області, загін прибув у Монастирський ліс і розмістився біля с. Нова Слобода Путивльського району. Однак, на нашу думку, офіційного оформлення загону так і не відбулося, про що свідчить відсутність наказів. Не вів загін і бойової та диверсійної роботи, оскільки до 10 жовтня 1941 р. у цій місцевості діяв фронт. А тому, основним завданням партизанів було проведення розвідки в районі дислокації й передача розвідданих військовим частинам. Після відступу фронту С. В. Руднєв почав активний пошук зв'язку з Путивльським партизанським загоном під командуванням С. А. Ковпака.

Наказом № 11 по Путивльському партизанському загону від 18 вересня 1941 р. Путивльські загони об’єднувалися в один загін під керівництвом: командир С. А. Ковпак, комісар С. В. Руднєв і начальник штабу Г. Я. Базима (його помічником було призначено М. М. Курса) [42, арк. 7-8]. Внаслідок об'єднання загін поповнився 21 партизаном із загону С. В. Руднєва і налічував 57 чоловік [41, арк. 5; 42, арк. 7].

Таким чином, 18 вересня 1941 р. розпочався об'єднавчий процес, що завершився в лютому 1942 р. створенням Путивльського об’єднаного партизанського загону. Так, 22 вересня 1941 р. до Путивльського партизанського загону приєдналися Харківський партизанський загін під командуванням М. Й. Воронцова (на умовах самостійної бойової одиниці) та партизанський загін під командуванням голови колгоспу с. Воргол Путивльського району С. Ф. Кириленка, який розпочав свою діяльність ще 6 вересня 1941 р. [42, арк. 13-15; 43, арк. 1-5зв].

3 цього часу структуру Путивльського партизанського загону було розширено і до його складу входило 8 оперативних груп. До перших п’яти груп увійшли партизани загонів С. А. Ковпака та С. В. Руднєва: 1-у групу (група підривників) із 10 чол. очолив М. М. Курс; 2-гу групу 317 чол. очолив П. Н. Васильєв, 3-у групу 316 чол. Ф. А. Карпенко, 4-у групу з 12 чол. - П. С. Пятишкін, 5-у групу з 10 чол., основу якої склали партизани з Конотопського району, очолив Ф. С. Канавець. 6-а група налічувала 19 чол. із загону С. Ф. Кириленка. 7-а й 8-а групи складалися з партизанів Харківського загону М. Й. Воронцова, їх кількість становила 11 і 13 чоловік під командуванням А. С. Сидоренка та І. П. Маника відповідно (вибули із загону в повному складі 7 листопада 1941 р. [42, арк. 23]). Відокремленою була група розвідки та зв'язку в кількості 11 чол., на яку покладалося завдання забезпечувати зв'язок із штабом загону та виведення оперативних груп на місце виконання оперативних завдань, а також ведення розвідки. Окремо діяла і господарська частина, яку очолив П. І. Дем'яненко й до якої входив його заступник Ф. С. Мерзляков та ще 4 чол. На них покладалися обов'язки забезпечувати партизанський загін продуктами харчування та боєприпасами [42, арк. 13-15; 43, арк. 1-5].

Наказом № 28 від 27 жовтня 1941 р. у Путивльському партизанському загоні було сформовано артилерійську частину під командуванням В. Ф. Петрова. Ї̈̈ особовий склад ділився на окремі групи: 4 чол. прикріплено в танковий екіпаж, командиром визначено Г. А. Жуковця (танк було відбито у німців у бою 19 жовтня); 8 чол. увійшло до артилерійської батареї, командиром якої призначено Г. С. Волкова. Крім того, в загоні було організовано санітарну частину із 3 чол. - жінок-військовослужбовців, які тимчасово 
ISSN 2518-1521 (Online), ISSN 2226-2830 (Print)

ВІСНИК МАРІУПОЛЬСЬКОГО ДЕРЖАВНОГО УНІВЕРСИТЕТУ

СЕРІЯ: ІСТОРІЯ. ПОЛІТОЛОГІЯ, 2019, ВИП. 25

перебували в загоні під час виходу з німецького оточення (начальник С. В. Шубякіна), а також агітаційну групу із 5 чол. для проведення роботи серед населення району (старший групи О. Л. Шпитальний) [42, арк. 19-20]. А вже 5 листопада, 3 метою “проведення політико-виховної роботи серед бійців оперативних груп”, командуванням загону було прийнято рішення про призначення в групи політруків [42, арк. 22].

Отже, за період від серпня 1941 р. до січня 1942 р., в окремих районах Сумської області сформувалися партизанські загони, що функціонували як самостійні бойові одиниці, диверсійна та бойова діяльність яких на місцях їхньої дислокації поступово активізовувалась, а особовий склад постійно поповнювався (хоча й були і зворотні процеси). В той же час, посилення збройного тиску німців викликало необхідність в об'єднанні для ведення спільної боротьби з ворогом. Наказами № 51 по Глухівському партизанському загону від 27 січня 1942 р. та № 68 по Путивльському партизанському загону від 29 січня, Путивльський партизанський загін об'єднувався з Глухівським партизанським загоном у складі 24 чол. Загін перейменовувався на оперативну групу № 7 та мав проводити свою оперативну роботу під загальним керівництвом командування Путивльського партизанського загону. Керівництво Глухівського загону залишалося незмінним (командир П. Л. Кульбака, комісар Г. І. Ковальов, начальник штабу С. К. Самойленко) [42, арк. 58; 46, арк. 113в].

Наказами № 28 по Шалигінському партизанському загону від 31 січня 1942 р. та № 70 по Путивльському партизанському загону від 1 лютого, Путивльський партизанський загін об'єднувався із Шалигінським партизанським загоном у складі 13 чоловік. Умови об'єднання були такими ж, як і з Глухівським загоном. Командний склад тепер уже оперативної групи № 8 залишався незмінним: командир А. Я. Саганюк, комісар Ф. Д. Матющенко, начальник штабу Ф. С. Фесенко [42, арк. 63; 47, арк. 22-23].

У зв'язку з масовим поповненням партизанського загону жителями навколишніх сіл, новоприбулі бійці або вливалися до вже існуючих оперативних груп (загонів), або ж формували нові групи за територіальною ознакою, які продовжували діяти як окремі бойові одиниці. Так, перебуваючи в Глухівському районі, Путивльський об'єднаний партизанський загін на початку лютого 1942 р. сформував оперативні групи № 9 та № 10 із військовозобов'язаних жителів сіл Зазерки (у кількості 20 чол.) та Узинець (21 чол.) відповідно. Щоправда, вже 11 лютого оперативна група № 9 влилась у склад опергрупи № 7 (Глухівський партизанський загін), а замість неї 14 лютого було створено нову -3 прибулих із Стрельниківської сільської ради Путивльського району 19 військовозобов'язаних під командуванням О. Д. Бардашенка. Оперативна група № 10 продовжувала діяти як окремий підрозділ під командуванням В. І. Лисенка та постійно поповнювалася новими бійцями з місцевих мешканців [42, арк. 76-77, 84-85]. 17 лютого із 21 військовозобов'язаного с. Литвиновичі Путивльського району було сформовано оперативну групу № 11 під командуванням М. І. Павловського [42, арк. 89-90].

Наказом № 82 від 22 лютого 1942 р. при Путивльському партизанському загоні організовувалась оперативна група № 12 із представників прибулого Кролевецького партизанського загону під керівництвом: командир В. М. Кудрявський, комісар К. І. Онопченко, начальник господарської частини Г. С. Іванько. До неї також вливались представники Середино-Будського партизанського загону під командуванням Г. С. Іванька та П. С. Дорошенка [42, арк. 99].

Створюючи нові підрозділи в загоні, командування намагалось дотримуватися територіального принципу. В той же час, суттєве збільшення кількості партизанів взимку 
ISSN 2518-1521 (Online), ISSN 2226-2830 (Print) ВІСНИК МАРІУПОЛЬСЬКОГО ДЕРЖАВНОГО УНІВЕРСИТЕТУ СЕРІЯ: ІСТОРІЯ. ПОЛІТОЛОГІЯ, 2019, ВИП. 25

1942 р. спонукало до розгалуження вже існуючої структури. Так, 11 лютого 1942 р., наказом № 75 по Путивльському об’єднаному партизанському загону, оперативні групи №№ 2, 3, 4, 5, 6, основу яких складали партизани колишніх загонів С. А. Ковпака та С. В. Руднєва, були поділені на три відділення кожна; оперативна група № 8 (Шалигінський загін) - на дві групи, які, в свою чергу, ділились на два відділення кожна; господарська частина також ділилась на два відділення [42, арк. 79-80].

В наступний період існування, лютий 1942 р.-лютий 1944 р., Путивльський об’єднаний партизанський загін (група партизанських загонів Сумської області, Сумське партизанське з'єднання) суттєво зріс у кількісному складі, приєднав нові бойові одиниці, змінив свою структуру тощо. У перші місяці 1942 р. в його складі діяло вже 7 окремих бойових одиниць - загонів (оперативних груп): Путивльський партизанський загін (командир С. А. Ковпак, комісар С. В. Руднєв, начальник штабу Г. Я. Базима); 1-й Глухівський партизанський загін (командир П. Л. Кульбака, комісар О. П. Білявський (згодом - П. Г. Шульга, Г. І. Ковальов), начальник штабу І. С. Лисиця); 2-й Глухівський партизанський загін (командир I. С. Чайка (згодом - I. В. Чубун), комісар І. Д. Клещенко); Шалигінський партизанський загін (командир А. Я. Саганюк, комісар Ф. Д. Матющенко, начальник штабу Ф. С. Фесенко); Шалигінський партизанський загін ім. В. І. Леніна (командир М. І. Ганзін, комісар К. О. Наливайко, начальник штабу С. Г. Максимов); Кролевецький партизанський загін (командир В. М. Кудрявський, комісар I. Г. Токар, начальник штабу П. О. Брайко); Конотопський партизанський загін (командир В. П. Кочемазов, комісар Ф. С. Канавець, начальник штабу Є. І. Байдін) [38, с. 49-50].

Сформована у перший період діяльності структура Сумського партизанського з’єднання, що грунтувалася на територіальному принципі, час від часу реорганізовувалась, однак в загальному вигляді залишалась сталою. Такі зміни організаційного характеру були викликані передусім умовами перебування у ворожому тилу та необхідністю ефективного ведення бойової діяльності. Так, 23 жовтня 1942 р., напередодні виходу в рейд на Правобережну Україну, “для забезпечення маскування на марші та під час перебування в районі дії партизанських загонів” з'єднання отримало назву “військова частина № 00105”, а його загони почали називатись батальйонами, оперативні групи - ротами 3 порядковим номером групи: Путивльський партизанський загін - 1-й батальйон, Глухівський загін - 2й батальйон, Шалигінський загін - 3-й батальйон, Кролевецький загін-окрема рота. Заборонялося вживати прізвища особового командного складу, а використовувати лише їх військові звання чи займані посади [42, арк. 298-299]. У травні 1943 р., перед виходом з'єднання у Карпатський рейд, номер військової частини було замінено на 00117, який використовувався до присвоєння № 00120 у лютому 1944 р. [44, арк. 143; 45, арк. 47].

Суттєві кадрові зміни у командному складі Сумського партизанського з'єднання відбулися в результаті Карпатського рейду (12 червня - 1 жовтня 1943 р.). В ході рейду втрати партизанів вбитими і пораненими сягали до 600 чоловік. Передусім, це стосувалося вищого командування з'єднання: в бою біля м. Делятин Івано-Франківської області загинув комісар з'єднання С. В. Руднєв; був також тяжко поранений начальник штабу Г. Я. Базима. В результаті цих змін, а також враховуючи бойову обстановку на окупованій території України та подальші плани діяльності, постановою Політбюро ЦК КП(б)У від 22 лютого 1944 р. Сумське з'єднання партизанських загонів було перейменовано на 1-у Українську партизанську дивізію ім. двічі Героя Радянського Союзу С. А. Ковпака [39, арк. 33-34]. Цією ж постановою, а також наказом № 505 уже по дивізії від 25 лютого 1944 р., визначалась структура та командний склад цієї бойової одиниці, 
ISSN 2518-1521 (Online), ISSN 2226-2830 (Print)

ВІСНИК МАРІУПОЛЬСЬКОГО ДЕРЖАВНОГО УНІВЕРСИТЕТУ

СЕРІЯ: ІСТОРІЯ. ПОЛІТОЛОГІЯ, 2019, ВИП. 25

зокрема, батальйони реорганізовувалися в полки, роти-в батальйони. Так, 1-й стрілецький батальйон перейменовувався в 1-й полк ім. Героя Радянського Союзу C. В. Руднєва (командир Д. І. Бакрадзе, начальник штабу I. І. Бережний); 2-й і 3-й стрілецькі батальйони - відповідно в 2-й полк (командир П. Л. Кульбака, начальник штабу О. П. Ільїн) і 3-й полк (командир П. О. Брайко, начальник штабу С. Ф. Абрамов). Кожен полк у своєму складі мав по два батальйони, які включали в себе три роти, а ті складалися з трьох взводів. При штабі дивізії діяли кавалерійський дивізіон у складі двох ескадронів (командир О. М. Ленкін, начальник штабу С. П. Тутученко); окрема рота пішої розвідки (командир Р. О. Клейн); артилерійська батарея 76 мм гармат (командир Г. Г. Тюпов); мінерна рота (командир С. В. Кальницький), санітарна частина (начальник санслужби Д. Ф. Скрипніченко), господарська частина (старшина штабних підрозділів О. І. Зільберглейт), комендантський взвод (комендант К. О. Дудник). Вищим керівництвом дивізії були: командир-підполковник П. П. Вершигора, начальник штабу-старший лейтенант В. О. Войцехович. 3 метою конспірації дивізії присвоювався новий номер військової частини - 00120 [38, с. 50; 45, арк. 453в-47]. Перейшовши на армійський порядок і залишивши посади комісарів лише на середньому рівні-в батальйонах, командування дивізії уже 5 червня вимушене було затвердити в ротах усіх полків посади “заступників помічників рот по політичній частині” [45, арк. 883в-89]. Найвищу посаду в цій ієрархії - заступник командира дивізії по політичній частині, фактично комісар, посів М. О. Москаленко.

Постановою Політбюро ЦК КП(б)У від 18 серпня 1944 р. 1-a Українська партизанська дивізія ім. С. А. Ковпака у повному складі, $з$ усім озброєнням, засобами зв'язку та майном передавалася в розпорядження Народного комісаріату внутрішніх справ (НКВС) УРСР для ведення боротьби проти військових сил Української повстанської армії [40, арк. 117-119; 45, арк. 125]. 8 листопада 1944 р. дивізію було розформовано і на їі базі створено окрему кавалерійську бригаду внутрішніх військ НКВС УРСР. У той же час, слід враховувати, що в період перебування в підпорядкованості НКВС УРСР, дивізія фактично перестала бути партизанським формуванням у класичному розумінні, а бійці, що вступали до неї в цей час, не мали статусу партизанів.

Таким чином, в Сумському партизанському з'єднанні діяла чітко вибудувана розгалужена структура із вдало підібраним командним складом, в основному сформована в перший період його діяльності. Впродовж усього часу існування цієї бойової одиниці їі структурна організація та командування зазнали певних змін, однак загалом залишалися сталими. Сформувавшись у лютому 1942 р. в об'єднання партизанських загонів Сумської області під командуванням С. А. Ковпака, С. В. Руднєва та Г. Я. Базими, ця бойова одиниця в такому організаційному та командному складі проіснувала до серпня 1943 р. й, у зв'язку з загибеллю і пораненням основного складу вищого командування, а також 3 метою ефективного виконання чергового бойового завдання, у лютому 1944 р. була реорганізована в 1-у Українську партизанську дивізію ім. двічі Героя Радянського Союзу C. А. Ковпака під командуванням П. П. Вершигори, М. О. Москаленка та В. О. Войцеховича. Основним принципом формування структурних підрозділів з'єднання (загони, оперативні групи, батальйони, полки) був територіальний. Основними чинниками, що впливали на структурні зміни, були зростання особового складу партизанів, активізація бойової й диверсійної діяльності, необхідність виконання бойових завдань, пов'язаних із рейдами по окупованій території України тощо. 
ISSN 2518-1521 (Online), ISSN 2226-2830 (Print) ВІСНИК МАРІУПОЛЬСЬКОГО ДЕРЖАВНОГО УНІВЕРСИТЕТУ СЕРІЯ: ІСТОРІЯ. ПОЛІТОЛОГІЯ, 2019, ВИП. 25

\section{Список використаної літератури}

1. Базима Г. Я. Слідами великого рейду : спогади партизана / Г. Я. Базима. - Київ : Молодь, 1959. - 367 c.; Bazyma H. Ya. Slidamy velykoho reidu : spohady partyzana / H.Ya. Bazyma. - Kyiv : Molod, 1959. - 367 s.

2. Бакрадзе Д. И. Карпатский рейд / Д. И. Бакрадзе. - Москва: Издательство ДОСААФ, 1968. - 160 с. ; Bakradze D. I. Karpatskiy reyd / D. I. Bakradze. - Moskva: Izdatelstvo DOSAAF, 1968. - $160 \mathrm{~s}$.

3. Бакрадзе Д. И. Кровью героев : (Записки участника партизанского соединения Ковпака) / Д. И. Бакрадзе. - Тбилиси : Заря Востока, 1961. - 516 с. ; Bakradze D. Y. Kroviu heroev. (Zapysky uchastnyka partyzanskoho soedynenyia Kovpaka) / D. Y. Bakradze. - Tbylysy: Zaria Vostoka, 1961. - $516 \mathrm{~s}$.

4. Білоус О. П. Діяльність радянських партизанів на території Північно-Східної України в 1941-1943 рр. : автореф. дис. ... канд. іст. наук : спец. 07.00.01 / Олександр Павлович Білоус; Київський національний університет ім. Т. Шевченка. - Київ, 2014.18 c. ; Bilous O. P. Diialnist radianskykh partyzaniv na terytorii Pivnichno-Skhidnoi Ukrainy v 19411943 rr. : avtoref. dys. ... kand. ist. nauk : spets. 07.00.01 / Oleksandr Pavlovych Bilous; Kyivskyi natsionalnyi universytet im. T. Shevchenka. - Kyiv, 2014. $-18 \mathrm{~s}$.

5. Білоус О. П. Початок бойової діяльності та перші бойові рейди Сумського партизанського з'єднання в 1941-1942 pp. /О.П.Білоус // Гуржіївські історичні читання. 2013. - Вип. 6. - С. 325-328 ; Bilous O. P. Pochatok boiovoi diialnosti ta pershi boiovi reidy Sumskoho partyzanskoho z'iednannia v 19411942 rr. /O. P. Bilous // Hurzhiivski istorychni chytannia. - 2013. - Vyp. 6. - S. 325-328.

6. Брайко П. Е. Внимание, Ковпак! / П. Е. Брайко, О.С.Калиненко. - Москва : Издательство ДОСААФ, 1971. - 351 с. ; Brayko P. Ye. Vnimanie, Kovpak! / P. Ye. Brayko, O. S. Kalinenko. - Moskva : Izdatelstvo DOSAAF, 1971. - $351 \mathrm{~s}$.

7. Вершигора П. П. Карпатский рейд. Из записок / П. П. Вершигора. - Москва : Правда, 1951. - 64 c. ; Vershigora P. P. Karpatskiy reyd. Iz zapisok / P. P. Vershigora. - Moskva : Pravda, 1951. $-64 \mathrm{~s}$.

8. Вершигора П. П. Люди с чистой совестью / П. П. Вершигора. - Киев : Политиздат, 1990. - 699 c. ; Vershigora P. P. Lyudi s chistoy sovestyu / P. P. Vershigora. - Kiev : Politizdat, 1990. $-699 \mathrm{~s}$.

9. Вершигора П. П. Переправа. Невигадані пригоди / П.П.Вершигора. - Київ : Обласне книжково-газетне видавництво, 1961.- 178 c.; Vershyhora P. P. Pereprava. Nevyhadani pryhody / P. P. Vershyhora. - Kyiv : Oblasne knyzhkovo-hazetne vydavnytstvo, 1961. $-178 \mathrm{~s}$.

10. Вершигора П. П. Рейд на Сян і Віслу / П. П. Вершигора. - Київ : Дніпро, 1968. 240 c. ; Vershyhora P. P. Reid na Sian i Vislu / P. P. Vershyhora. - Kyiv : Dnipro, 1968. - 240 s.

11. Вершигора П. П. Партизанские рейды : (Из истории партизанского движения в годы Великой Отечественной войны Советского Союза 1941-1945 гг.) / П. П. Вершигора, В. А. Зеболов. - Кишинев : Штиинца, 1962. - 136 с. ; Vershigora P. P. Partizanskie reydy : (Iz istorii partizanskogo dvizheniya v gody Velikoy Otechestvennoy voyny Sovetskogo Soyuza 1941 1945 gg.) / P. P. Vershigora, V. A. Zebolov. - Kishinev : Shtiintsa, 1962. - 136 s.

12. Від Полісся до Карпат: Карпатський рейд Сумського партизанського з'єднання під командуванням С. А. Ковпака (червень - вересень 1943 р.) очима учасників, мовою документів / упоряд. : А. В. Кентій, В. С. Лозицький. - Київ: Парламентське видавництво, 2005. - 304 c. ; Vid Polissia do Karpat: Karpatskyi reid Sumskoho partyzanskoho ziednannia pid 
ISSN 2518-1521 (Online), ISSN 2226-2830 (Print)

ВІСНИК МАРІУПОЛЬСЬКОГО ДЕРЖАВНОГО УНІВЕРСИТЕТУ

СЕРІЯ: ІСТОРІЯ. ПОЛІТОЛОГІЯ, 2019, ВИП. 25

komanduvanniam S. A. Kovpaka (cherven - veresen 1943 r.) ochyma uchasnykiv, movoiu dokumentiv / uporiad. : A. V. Kentii, V. S. Lozytskyi. - Kyiv: Parlamentske vydavnytstvo, 2005. $-304 \mathrm{~s}$.

13. Власенко С. I. Радянський партизанський рух опору в період звільнення території України та країн Центральної і Південно-Східної Свропи (1943-1945 рp.) / С. І. Власенко // Архіви України. - 2015. - № 3. - C. 69-79; Vlasenko S. I. Radianskyi partyzanskyi rukh oporu v period zvilnennia terytorii Ukrainy ta krain Tsentralnoi i Pivdenno-Skhidnoi Yevropy (1943-1945 rr.) / S. I. Vlasenko // Arkhivy Ukrainy. - 2015. - № 3. - S. 69-79.

14. Власенко С. I. Степовий рейд з'єднання Українських кавалерійських партизанських загонів (за документами ЦДАГО України) / С. I. Власенко // Сумський історико-архівний журнал. - 2014. - № 22. - С. 79-88 ; Vlasenko S. I. Stepovyi reid ziednannia Ukrainskykh kavaleriiskykh partyzanskykh zahoniv (za dokumentamy TsDAHO Ukrainy) / S.I. Vlasenko // Sumskyi istoryko-arkhivnyi zhurnal. - 2014. - № 22. - S. 79-88.

15. Войцехович В. О. Партизани ідуть на захід/ В. О. Войцехович. - Київ : Політвидав України, 1982. - 256 c.; Voitsekhovych V. O. Partyzany idut na zakhid / V.O. Voitsekhovych. - Kyiv : Politvydav Ukrainy, 1982. - 256 s.

16. Войцехович В. О. Сто днів звитяги : Партизанські зшитки : Про героїчний похід у Карпати у 1943 р. партизанського з’єднання Ковпака-Руднєва / В. О. Войцехович. Київ : Радянський письменник, 1970.- 323 с.; Voitsekhovych V. O. Sto dniv zvytiahy : Partyzanski zshytky : Pro heroichnyi pokhid u Karpaty u 1943 r. partyzanskoho ziednannia Kovpaka - Rudnieva / V. O. Voitsekhovych. - Kyiv : Radianskyi pysmennyk, 1970. - 323 s.

17. Вронська Т. В. Специфічні форми і методи боротьби радянських партизанів на території окупованої України / Т. В. Вронська // Сторінки воєнної історії України. - 2010. Вип. 13. - С. 185-201 ; Vronska T. V. Spetsyfichni formy i metody borotby radianskykh partyzaniv na terytorii okupovanoi Ukrainy / T. V. Vronska // Storinky voiennoi istorii Ukrainy. 2010. - Vyp. 13. - S. 185-201.

18. Дахненко М. В. Життя та діяльність С. А. Ковпака (1887-1967 рр.) : дис. ... канд. іст. наук : спец. 07.00.01 / Марина Валеріївна Дахненко; Київський національний університет ім. Т. Шевченка. - Київ, 2013. - 192 с. ; Dakhnenko M. V. Zhyttia ta diialnist S. A. Kovpaka (1887 1967 rr.) : dys. ... kand. ist. nauk : spets. 07.00 .01 / Maryna Valeriivna Dakhnenko; Kyivskyi natsionalnyi universytet im. T. Shevchenka. - Kyiv, 2013. - $192 \mathrm{~s}$.

19. Дученко Ю. М. Розвиток форм і способів антифашистської боротьби на території України в роки Другої світової війни (1941-1945рр.) : дис. ... канд. іст. наук : спец. 20.02.22 / Юрій Миколайович Дученко; Національний університет „Львівська політехніка". - Львів, 2009 - 176 с.; Duchenko Yu. M. Rozvytok form i sposobiv antyfashystskoi borotby na terytorii Ukrainy v roky Druhoi svitovoi viiny (1941-1945 rr.) : dys. ... kand. ist. nauk : spets. 20.02.22 / Yurii Mykolaiovych Duchenko; Natsionalnyi universytet „Lvivska politekhnika”. - Lviv, 2009 - 176 s.

20. Капась I. А. Радянський рух Опору в Україні: організація, легітимізація, меморіалізація (1941-1953 рр.) / I. А. Капась. - Київ : К.І.С., 2016. - 208 с. ; Караs I. А. Radianskyi rukh Oporu v Ukraini: orhanizatsiia, lehitymizatsiia, memorializatsiia (1941-1953 rr.) / I. A. Kapas. - Kyiv : K.I.S., 2016. - 208 s. ;

21. Кентій А. В. Боротьба в тилу нацистських окупантів в Україні: радянські партизани у 1941-1944 pp. / А. В. Кентій, В. С. Лозицький // Україна в Другій світовій війні: погляд з XXI ст. Історичні нариси. - Київ : Наукова думка, 2011. - Кн. 1. - С. 512541 ; Kentii A. V. Borotba v tylu natsystskykh okupantiv v Ukraini: radianski partyzany u 1941- 
ISSN 2518-1521 (Online), ISSN 2226-2830 (Print) ВІСНИК МАРІУПОЛЬСЬКОГО ДЕРЖАВНОГО УНІВЕРСИТЕТУ СЕРІЯ: ІСТОРІЯ. ПОЛІТОЛОГІЯ, 2019, ВИП. 25

1944 rr. / A. V. Kentii, V. S. Lozytskyi // Ukraina v Druhii svitovii viini: pohliad z XXI st. Istorychni narysy. - Kyiv : Naukova dumka, 2011. - Kn. 1. - S. 512-541.

22. Кентій А. В. Війна без пощади і милосердя: Партизанський рух в тилу вермахту в Україні. 1941-1944 рр. / А. В. Кентій, В. С. Лозицький. - Київ : Генеза, 2005. - 408 с. ; Kentii A. V. Viina bez poshchady i myloserdia: Partyzanskyi rukh v tylu vermakhtu v Ukraini. 1941-1944 rr. / A. V. Kentii, V. S. Lozytskyi. - Kyiv : Heneza, 2005. - 408 s.

23. Кентій А. Радянські партизани 1941-1944: світло й тіні / А. Кентій, В. Лозицький. - Київ : Н. Брехуненко, 2010. - 80 с. ; Kentii A. Radianski partyzany 19411944: svitlo y tini / A. Kentii, V. Lozytskyi. - Kyiv : N. Brekhunenko, 2010. - 80 s.

24. Кентій А. В. Радянський рух Опору на окупованій території України / А. В. Кентій, В. С. Лозицький, М. Слободянюк. - Київ : Інститут історії України, 2010. 97 c. ; Kentii A. V. Radianskyi rukh Oporu na okupovanii terytorii Ukrainy / A. V. Kentii, V.S. Lozytskyi, M. Slobodianiuk. - Kyiv : Instytut istorii Ukrainy, 2010. - 97 s.

25. Коваль М. В. Україна в Другій світовій і Великій Вітчизняній війнах (19391945 рр.) / М. В. Коваль; за заг. ред. В. Смолія. - Київ : Альтернативи, 1999. - 336 с. (Україна крізь віки. У 15-ти тт. - Т. 12) ; Koval M. V. Ukraina v Druhii svitovii i Velykii Vitchyznianii viinakh (1939-1945 rr.) / M. V. Koval; za zah. red. V. Smoliia. - Kyiv : Alternatyvy, 1999. - 336 s. - (Ukraina kriz viky. U 15-ty tt. - T. 12).

26. Ковпак С. А. Від Путивля до Карпат / С. А. Ковпак. - Київ : Політвидав України, 1984. - 287 c. ; Kovpak S. A. Vid Putyvlia do Karpat / S. A. Kovpak. - Kyiv : Politvydav Ukrainy, 1984. -287 s.

27. Ковпак С. А. Воспоминания, очерки, статьи / С. А. Ковпак; сост.: В. А. Замлинский. - Київ : Политиздат Украины, 1987. - 388 с. ; Kovpak S. A. Vospominaniya, ocherki, stati / S. A. Kovpak; sost.: V. A. Zamlinskiy. - Kï̀v : Politizdat Ukrainy, 1987. - $388 \mathrm{~s}$.

28. Ковпак С. А. Из дневника партизанских походов / С. А. Ковпак; лит. запись: В. А. Неверович. - Москва : Издательство ДОСААФ, 1964. - 219 с. ; Kovpak S. A. Iz dnevnika partizanskikh pokhodov / S. A. Kovpak; lit. zapis: V. A. Neverovich. - Moskva : Izdatelstvo DOSAAF, 1964. - 219 s.

29. Ковпак С. А. Партизанскими тропами / С. А. Ковпак; лит. запись : А. С. Палей. Москва : Знание, 1965. - 62 с. ; Kovpak S. A. Partizanskimi tropami / S. A. Kovpak; lit. zapis : A. S. Paley. - Moskva : Znanie, 1965. - 62 s.

30. Ковпак С. А. Сталинский рейд / С. А. Ковпак; лит. запись: Е. Герасимов. Москва : Воениздат, 1947. - 76 с. ; Kovpak S. A. Stalinskiy reyd / S. A. Kovpak; lit. zapis: Ye. Gerasimov. - Moskva : Voenizdat, 1947. - 76 s.

31. Лисенко О. Є. Джерелознавчі аспекти дослідження історії партизанського руху в Україні 1941-1944 pp. / О. С. Лисенко // Спеціальні історичні дисципліни: питання теорії та методики. - 2001. - № 7. - C. 79-93 ; Lysenko O. Ye. Dzhereloznavchi aspekty doslidzhennia istorii partyzanskoho rukhu v Ukraini 1941-1944 rr. / O. Ye. Lysenko // Spetsialni istorychni dystsypliny: pytannia teorii ta metodyky. - 2001. - № 7. - S. 79-93.

32. Лозицький В. С. До питання про загальну чисельність партизанів УРСР у роки Великої Вітчизняної війни (1941-1945рр.)/ В. С. Лозицький // Український історичний журнал. - 2011. - № 6. - C. 152-171 ; Lozytskyi V. S. Do pytannia pro zahalnu chyselnist partyzaniv URSR u roky Velykoi Vitchyznianoi viiny (1941-1945 rr.) / V. S. Lozytskyi // Ukrainskyi istorychnyi zhurnal. - 2011. - № 6. - S. 152-171. 
ISSN 2518-1521 (Online), ISSN 2226-2830 (Print)

ВІСНИК МАРІУПОЛЬСЬКОГО ДЕРЖАВНОГО УНІВЕРСИТЕТУ

СЕРІЯ: ІСТОРІЯ. ПОЛІТОЛОГІЯ, 2019, ВИП. 25

33. Партизанская война на Украине: Дневники командиров партизанских отрядов и соединений. 1941-1944 / колл. сост. : О. В. Бажан, С. И. Власенко, Л. В. Легасова, В. С. Лозицкий (рук.). - Москва : ЗАО Издательство Центрполиграф, 2010. - 670 с. ; Partizanskaya voyna na Ukraine: Dnevniki komandirov partizanskikh otryadov i soedineniy. 1941-1944 / koll. sost. : O. V. Bazhan, S. I. Vlasenko, L. V. Legasova, V. S. Lozitskiy (ruk.). Moskva : ZAO Izdatelstvo Tsentrpoligraf, 2010. - $670 \mathrm{~s}$.

34. Руднев С. В. Легендарный рейд. (Дневник о Карпатском рейде. Письма) / C. В. Руднев. - Ужгород: Карпаты, 1967. - 200 c. ; Rudnev S. V. Legendarnyy reyd. (Dnevnik o Karpatskom reyde. Pisma) / S. V. Rudnev. - Uzhgorod: Karpaty, 1967. - 200 s.

35. Руднєв С. В. Щоденник про Карпатський рейд / С. В. Руднєв. - 3-є вид. Станіслав : Обласне книжково-газетне видавництво, 1960.- 84 с.; Rudniev S. V. Shchodennyk pro Karpatskyi reid / S. V. Rudniev. - 3-ye vyd. - Stanislav : Oblasne knyzhkovohazetne vydavnytstvo, 1960. $-84 \mathrm{~s}$.

36. Тутученко С. П. Лесные всадники / С. П. Тутученко. - Киев : Политиздат Украины, 1977. - 296 с. ; Tutuchenko S. P. Lesnye vsadniki / S. P. Tutuchenko. - Kiev : Politizdat Ukrainy, 1977. - 296 s.

37. Тутученко С. П. Люди, которых я знал / С. П. Тутученко. - Киев : Политиздат Украины, 1986. - 214 с. ; Tutuchenko S. P. Lyudi, kotorykh ya znal / S. P. Tutuchenko. - Kiev : Politizdat Ukrainy, 1986. - 214 s.

38. Україна партизанська 1941-1945. Партизанські формування та органи керівництва ними : наук.-довід. вид. / авт.-упоряд. : В. С. Лозицький та ін.; редкол. : В. А. Смолій (голова) та ін.; Центральний державний архів громадських об'єднань України. - Київ : Парламентське видавництво, 2001. - 319 с.; Ukraina partyzanska 1941 1945. Partyzanski formuvannia ta orhany kerivnytstva nymy : nauk.-dovid. vyd. / avt.-uporiad. : V. S. Lozytskyi ta in.; redkol. : V. A. Smolii (holova) ta in.; Tsentralnyi derzhavnyi arkhiv hromadskykh obiednan Ukrainy. - Kyiv : Parlamentske vydavnytstvo, 2001. - 319 s.

39. Центральний державний архів громадських об'єднань України (ЦДАГО України), ф. 1, оп. 16, спр. 53, 98 арк. ; Tsentralnyi derzhavnyi arkhiv hromadskykh obiednan Ukrainy (TsDAHO Ukrainy), f. 1, op. 16, spr. 53, 98 ark.

40. ЦДАГО України, ф. 1, оп. 16, спр. 54, 146 арк. ; TsDAHO Ukrainy, f. 1, op. 16, spr. 54, 146 ark.

41. ЦДАГО України, ф. 63, оп. 1, спр. 1, 91 арк. ; TsDAHO Ukrainy, f. 63, op. 1, spr. 1, 91 ark.

42. ЦДАГО України, ф. 63, оп. 1, спр. 8, 303 арк. ; TsDAHO Ukrainy, f. 63, op. 1, spr. 8, 303 ark.

43. ЦДАГО України, ф. 63, оп. 1, спр. 11, 196 арк. ; TsDAHO Ukrainy, f. 63, op. 1, spr. 11, 196 ark.

44. ЦДАГО України, ф. 63, оп. 1, спр. 15, 165 арк. ; TsDAHO Ukrainy, f. 63, op. 1, spr. 15, 165 ark.

45. ЦДАГО України, ф. 63, оп. 1, спр. 25, 141 арк. ; TsDAHO Ukrainy, f. 63, op. 1, spr. 25, 141 ark.

46. ЦДАГО України, ф. 63, оп. 1, спр. 191, 66 арк. ; TsDAHO Ukrainy, f. 63, op. 1, spr. 191, 66 ark.

47. ЦДАГО України, ф. 63, оп. 1, спр. 219, 211 арк. ; TsDAHO Ukrainy, f. 63, op. 1, spr. 219, 211 ark. 
ISSN 2518-1521 (Online), ISSN 2226-2830 (Print) ВІСНИК МАРІУПОЛЬСЬКОГО ДЕРЖАВНОГО УНІВЕРСИТЕТУ СЕРІЯ: ІСТОРІЯ. ПОЛІТОЛОГІЯ, 2019, ВИП. 25

48. Чайковський А. С. Невідома війна (Партизанський рух в Україні 1941-1945 рр. Мовою документів, очима історика)/ А. С. Чайковський. - Київ :1994. - 255 с. ; Chaikovskyi A. S. Nevidoma viina (Partyzanskyi rukh v Ukraini 1941-1945 rr. Movoiu dokumentiv, ochyma istoryka) / A. S. Chaikovskyi. - Kyiv :1994. - 255 s.

Стаття надійшла до редакції 05.06.2019 р.

\section{O. Verbovyi}

STRUCTURE AND COMMAND STAFF OF SUMY PARTISAN ASSOCIATION (1941-1944)

The article is devoted to the process of formation of the Putivl combined partisan detachment (the Sumy Partisan Association, the 1st Ukrainian Partisan Division named after twice Hero of the Soviet Union, S. A. Kovpak), the formation and evolution of its structure. The creation and activity at the initial stage of the Putivl partisan detachments under the command of S. A. Kovpak and S. V. Rudnev, the Glukhiv partisan detachment under the command of P. L. Kulbaki, the Shalygin partisan detachment A. Ya. Saganiuk, Konotop partisan detachment F. E. Canavets, Kharkiv partisan detachment M. Y. Vorontsov and others is analyzed. The process of formation of the Putivl combined partisan detachment under the command of S. A. Kovpak-S. V. Rudnev-G. Ya. Bazimi and the accession of independent partisan detachments to its complement, formation of the structure and command staff of the united detachment and its units was traced. The evolutionary changes in the structure of the partisan association according to the conditions of conducting military operations are analyzed. The changes in staffing of the command personnel of the Sumy partisan association were researched.

The personnel and structural changes connected with the process of association reconfiguration in the 1st Ukrainian Partisan Division named after twice Hero of the Soviet Union S. A. Kovpak under the command of P.P.VershigoraM. O. Moskalenko- V. O. Voitsekhovich are determined. The influence of staffing of the command staff on the success of the combat activity of the unit is monitored.

Key words: Ukraine during World War II, partisan resistance movement, Putivl united partisan detachment, Sumy Partisan Association, 1st Ukrainian Partisan Division named after twice Hero of the Soviet Union S. A. Kovpak.

УДК 930:94(477+438)”19/20»

\section{Ю.О. Конарівська}

\section{ДІЯЛЬНІСТЬ «СОЮЗУ ПОЛЬСЬКОГО НАРОДУ» НА ПРАВОБЕРЕЖНІЙ УКРАЇНІ В ІСТОРИЧНІЙ ЛІТЕРАТУРІ СЕРЕДИНИ ХХ - ПОЧАТКУ ХХІ СТ.}

У статті аналізуються праці істориків XX- поч. XXI cm., у яких досліджуються форми і напрямки діяльності польського таємного товариства «Союз польського народу» на території Правобережної Украӥни, метою якого була підготовка місиевого населення, зокрема, селянства, яке складалося переважно з украӥнців, до повстання за відновлення Речі Посполитої у кордонах 1772 р., щуо означало і включення до ї̈ складу Правобережної Украӥни та Галичини. 